\title{
Olefin cross metathesis based de novo synthesis of a partially protected L-amicetose and a fully protected L-cinerulose derivative
}

\author{
Bernd Schmidt ${ }^{*}$ and Sylvia Hauke
} Open Access

\author{
Full Research Paper \\ Address: \\ Institut für Chemie, Organische Synthesechemie, Universität \\ Potsdam, Karl-Liebknecht-Straße 24-25, 14476 Potsdam-Golm, \\ Germany \\ Email: \\ Bernd Schmidt ${ }^{*}$ - bernd.schmidt@uni-potsdam.de \\ * Corresponding author \\ Keywords: \\ carbohydrates; de novo synthesis; lactate; metathesis; ruthenium
}

Beilstein J. Org. Chem. 2014, 10, 1023-1031.

doi:10.3762/bjoc. 10.102

Received: 20 December 2013

Accepted: 11 April 2014

Published: 06 May 2014

Associate Editor: V. M. Dong

(c) 2014 Schmidt and Hauke; licensee Beilstein-Institut. License and terms: see end of document.

\begin{abstract}
Cross metathesis of a lactate derived allylic alcohol and acrolein is the entry point to a de novo synthesis of 4-benzoate protected $\mathrm{L}$-amicetose and a cinerulose derivative protected at $\mathrm{C} 5$ and $\mathrm{C} 1$.
\end{abstract}

\section{Introduction}

Many drugs and bioactive natural products are glycoconjugates, which contain an aglycon part linked through glycosidic bonds to one or more oligosaccharide side chains [1]. While it was assumed for quite some time that the carbohydrate side chain merely influences the pharmacokinetics, more recent investigations led to the conclusion that the oligosaccharide moiety contributes essentially to the mechanisms of action, e.g., through molecular recognition of a preferred binding site [2-5], thereby ensuring the selectivity of a chemotherapeutic agent. Particularly common are side chains composed of deoxygenated sugars [6]. For example, the kigamicins are bacterial secondary metabolites isolated from Amicolatopsis sp. [7,8] and display both antibiotic and cytotoxic activity [9]. They have a polycyclic xanthone aglycone in common, which is glycosylated at the $\mathrm{C} 14-\mathrm{OH}$ group. In Figure 1 the structure of kigamicin $\mathrm{B}$, which carries a $\mathrm{D}$-amicetose disaccharide unit, is shown as a representative example. Another antitumor antibiotic is aclacinomycin A, which has been used clinically under the name aclarubicin. It is an anthracycline [10] bearing a trisaccharide side chain consisting of L-rhodosamin, 2,6didesoxy-L-lyxose, and L-cinerulose attached to the aglycon aclavinon $[11,12]$. It was found to be a potent antineoplastic agent with particular activity against different forms of leukemia [13] (Figure 1).

Desoxy-sugars are sometimes scarcely available from natural sources and therefore the chemical syntheses of the monosaccharides [6,14] and their assembly to oligosaccharides [15-17] has attracted constant attention for many years. For example, D-amicetose has been obtained from other carbohydrates 

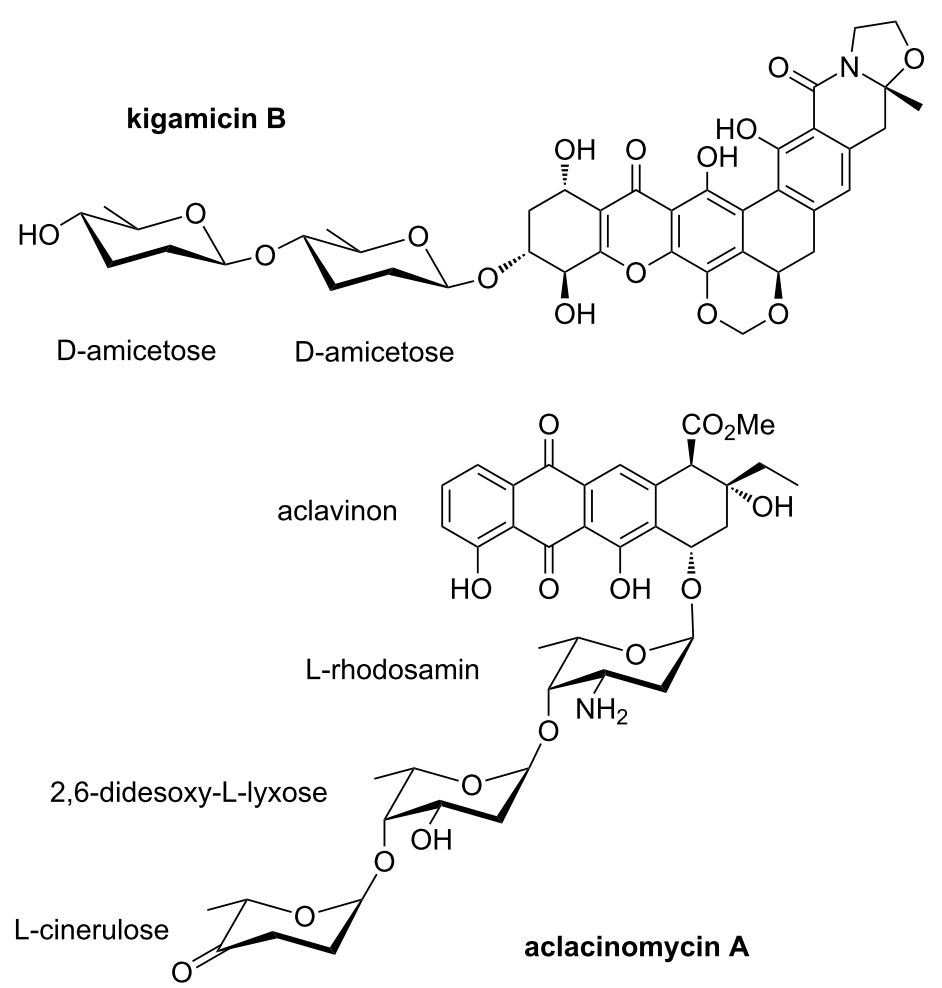

Figure 1: Structures of kigamicin B and aclacinomycin A as representative examples for antineoplastic glycoconjugates.

through ethanethiolysis and subsequent Ni-catalyzed desulfurization $[18,19]$, by reduction of the corresponding aldonolactone [20], or by conversion of a protected mannopyranoside into the 2,3-unsaturated enopyranoside and subsequent hydrogenation and reductive 6-deoxygenation [21,22]. Successful de novo approaches [14] to both enantiomers of amicetose include an Achmatowicz rearrangement-hydrogenation sequence, starting from enantiomerically pure 2-(1-hydroxyethyl)furan [23-25], a sequence comprising perdeuteration of an alkynoate derived from L-threonine (giving a 2,2,3,3-tetradeuterated amicetose) [26], enantioselective hydroboration of hetero Diels-Alder adducts [27], stereoconservative diazotation of L-glutamic acid $[28,29]$, diastereoselective addition of methylmagnesium bromide to enantiopure 2-benzyloxyhex-5-enal [30], oxidative degradation of aromatics and subsequent lactonization [31], and a two-carbon homologation of an enantiopure C4-building block with a metallated sulfone [32]. A combinatorial biosynthetic approach to D- and L-amicetose has also recently been established by combining different sugar biosynthesis genes [5].

Comparatively few transition metal mediated or -catalyzed reactions have hitherto been used for the synthesis of 2,3,6tridesoxy sugars such as amicetose. An example is the $\mathrm{W}$-promoted cycloisomerization of lactaldehyde derived alkynols, which yields the glycal of amicetose or its epimer rhodinose, respectively [33]. An approach to amicetose (and a few other 6-desoxy sugars) involves the formation of an enantiopure $\beta, \gamma$-unsaturated $\delta$-valerolactone via ring closing metathesis (RCM). The RCM product is subsequently converted into L-amicetose in four steps [34]. Unfortunately, the steps determining the configuration at $\mathrm{C} 4$ proceed in both cases with virtually no diastereoselectivity, although the resulting epimers were conveniently separated by chromatography. We have recently established two different metathesis based routes to L-amicetose [35] or L-amicetal [36], respectively, which both use enantiomerically pure L-ethyl lactate (1) as the starting material (Scheme 1). The synthetic routes rely on the highly diastereoselective two-step conversion of ethyl lactate to allylic alcohol 2 [36,37] and further to the RCM precursor 3, which then undergoes RCM-isomerization to L-amicetal 4 [36]. Alternatively, we have used $\mathbf{2}$ as a substrate for a cross metathesis reaction with methyl acrylate under isomerization-free conditions to furnish enoate 5, which underwent cyclization to the lactone $\mathbf{6}$ after hydrogenation. Reduction of $\mathbf{6}$ with DIBAL-H eventually yields a protected L-amicetose 7 [35]. To avoid the last step of the sequence, we envisaged a cross metathesis with acroleine, rather than methyl acrylate, to give enal 8 which should undergo spontaneous lactol formation after hydrogenation and desilylation. However, compared to cross metathesis 


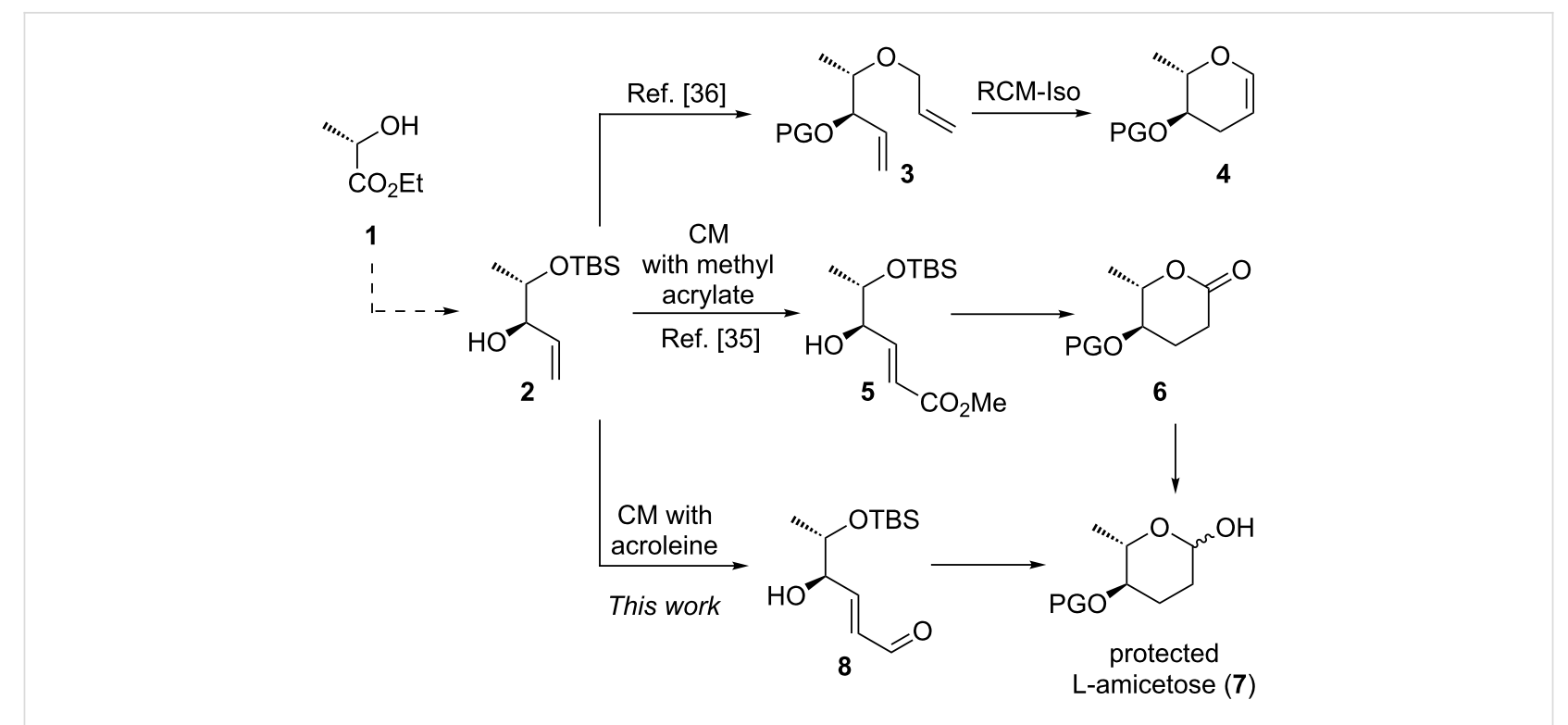

Scheme 1: RCM-isomerization approach to L-amicetal 4 and alternative CM approaches to L-amicetose.

reactions with methyl acrylate literature precedence for the use of acroleins as CM partner is significantly smaller [38-44].

In this contribution we report a de novo synthesis of a protected L-amicetose, using a cross metathesis reaction of allyl alcohol 2 with acrolein, and the elaboration of the cross metathesis product 8 to a fully protected acyclic cinerulose derivative. We are aware of only one previous de novo synthesis of DL-cinerulose, which used an Achmatowicz rearrangement of 2-(1-hydroxyethyl)furan [45].

\section{Results and Discussion}

The three second generation catalysts A [46], B [47,48] and C $[49,50]$ were initially tested for the cross metathesis of $\mathbf{2}$ and acrolein (Table 1). We started with the most common catalyst, the second generation Grubbs' catalyst. In order to suppress undesired double bond isomerization reactions $[51,52]$ we tried to avoid high reaction temperatures, which may cause catalyst decomposition to isomerization active species. This phenomenon has often been observed for second generation catalysts [53]. For these reasons, phenol was used as a rate accelerating additive. Phenols are believed to coordinate to the $\mathrm{Ru}$ and stabilize the catalytically active 14 -electron species, resulting in a retarded catalyst decomposition [54,55]. In the presence of $5 \mathrm{~mol} \%$ of $\mathbf{A}$ and 0.5 equiv of phenol, however, the yield of cross metathesis product $\mathbf{8}$ was very low at ambient temperature (Table 1, entry 1). Heating the mixture to reflux in dichloromethane resulted in a comparably low yield (Table 1, entry 2), whereas a significant improvement could be observed in toluene at $80^{\circ} \mathrm{C}$ (Table 1, entry 3 ). We thought that the yield could not be further increased with catalyst $\mathbf{A}$ and therefore decided to test the phosphine free catalyst $\mathbf{B}$. This and related catalysts [56], comprising a hemilabile ortho-isopropoxy substituted alkylidene ligand, are particularly suited for cross metathesis reactions $[57,58]$. Indeed, even at ambient temperature and without any rate accelerating additive, a good yield of $86 \%$ was obtained (Table 1 , entry 4 ), which could be improved to quantitative by increasing the reaction temperature to $40{ }^{\circ} \mathrm{C}$ (Table 1, entry 5). Reducing the catalyst loading to $2.5 \mathrm{~mol} \%$ is possible, but at the expense of isolated yield of product (Table 1, entry 6). We have previously used the Umicore M5 1 catalyst (C) [49] for cross metathesis reactions and discovered that high selectivities and rates of conversion can be accomplished even with comparatively low catalyst loadings $[59,60]$. For the cross metathesis of $\mathbf{2}$ and acroleine, $\mathbf{C}$ gave significantly better yields than $\mathbf{A}$, but was found to be inferior to $\mathbf{B}$ (Table 1, entries 7-9).

In the following step we decided to protect the hydroxy group at $\mathrm{C} 4$ first to avoid any complications arising from the formation of a furanose after hydrogenation of the $\mathrm{C}-\mathrm{C}$ double bond. Benzoyl was chosen as a protecting group, because of its $\mathrm{UV}$-activity, its orthogonality to the TBS group at $\mathrm{C} 5-\mathrm{OH}$ and its stability under hydrogenation conditions. Interestingly, attempted benzoylation in pyridine resulted exclusively in the formation of furan $\mathbf{1 0}$ (Table 2, entry 1 ). We reasoned that pyridine initiates an $E / Z$-isomerization of the enal through nucleophilic attack at the $\beta$-position, followed by lactol formation, benzoylation of the lactol and finally elimination of benzoic acid. Replacing pyridine as a solvent by dichloromethane and using NEt(iPr $)_{2}$ as an HCl-scavenger led indeed to a suppression of the formation of furan $\mathbf{1 0}$, but the desired benzoate 9 
Table 1: Catalyst screening for CM of allyl alcohol 2 and acrolein.
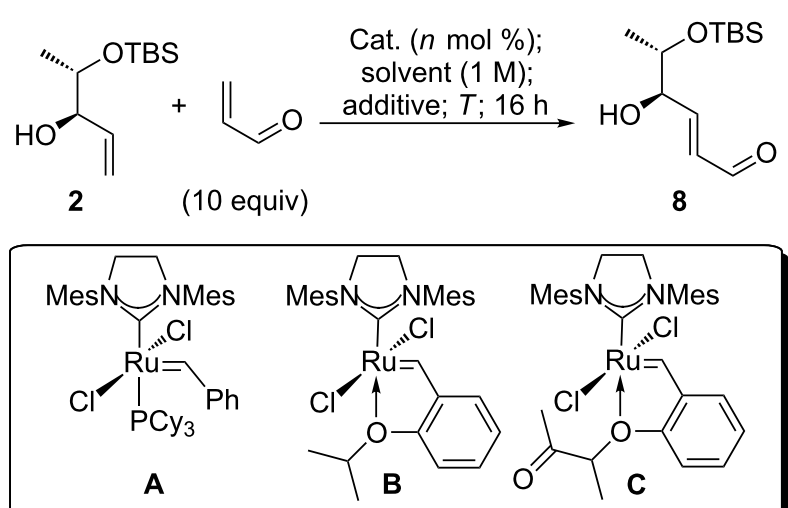

\begin{tabular}{|c|c|c|c|c|c|c|}
\hline entry & catalyst & cat. loading & additive (equiv) & solvent & $T /{ }^{\circ} \mathrm{C}$ & yield of 8 \\
\hline $1^{a}$ & A & $5 \mathrm{~mol} \%$ & phenol (0.5) & $\mathrm{CH}_{2} \mathrm{Cl}_{2}$ & $25^{\circ} \mathrm{C}$ & $25 \%$ \\
\hline $2^{a}$ & A & $5 \mathrm{~mol} \%$ & phenol (0.5) & $\mathrm{CH}_{2} \mathrm{Cl}_{2}$ & $40^{\circ} \mathrm{C}$ & $20 \%$ \\
\hline 3 & A & $5 \mathrm{~mol} \%$ & phenol (0.5) & toluene & $80^{\circ} \mathrm{C}$ & $68 \%$ \\
\hline 4 & B & $5 \mathrm{~mol} \%$ & - & $\mathrm{CH}_{2} \mathrm{Cl}_{2}$ & $25^{\circ} \mathrm{C}$ & $86 \%$ \\
\hline 5 & B & $5 \mathrm{~mol} \%$ & - & $\mathrm{CH}_{2} \mathrm{Cl}_{2}$ & $40^{\circ} \mathrm{C}$ & $99 \%$ \\
\hline 6 & B & $2.5 \mathrm{~mol} \%$ & - & $\mathrm{CH}_{2} \mathrm{Cl}_{2}$ & $40^{\circ} \mathrm{C}$ & $76 \%$ \\
\hline 7 & C & $5 \mathrm{~mol} \%$ & - & $\mathrm{CH}_{2} \mathrm{Cl}_{2}$ & $40^{\circ} \mathrm{C}$ & $65 \%$ \\
\hline 8 & C & $5 \mathrm{~mol} \%$ & - & toluene & $80^{\circ} \mathrm{C}$ & $80 \%$ \\
\hline 9 & C & $2.5 \mathrm{~mol} \%$ & - & toluene & $80^{\circ} \mathrm{C}$ & $65 \%$ \\
\hline
\end{tabular}

aAllylic alcohol 2 was recovered in $21 \%$ yield (entry 1 ) and in $12 \%$ yield (entry 2), respectively.

Table 2: $\mathrm{C} 4-\mathrm{OH}$ protection as benzoate.

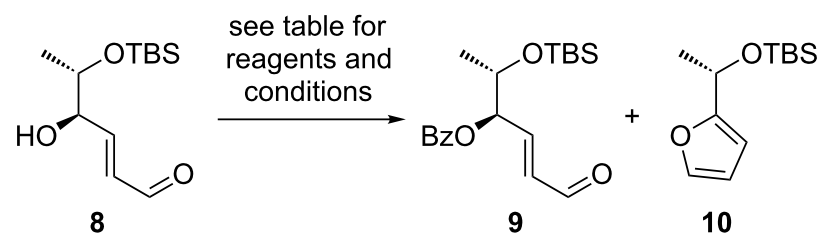

\begin{tabular}{|c|c|c|c|}
\hline entry & reagents and conditions & product & yield \\
\hline 1 & benzoyl chloride ( 1.5 equiv), pyridine $(0.4 \mathrm{M}), 65^{\circ} \mathrm{C}, 12 \mathrm{~h}$ & 10 & $47 \%$ \\
\hline $2^{a}$ & benzoyl chloride (2.6 equiv), $\mathrm{NEt}(\mathrm{iPr})_{2}$ (3.0 equiv), $\mathrm{CH}_{2} \mathrm{Cl}_{2}, 40{ }^{\circ} \mathrm{C}, 12 \mathrm{~h}$ & 9 & $<20 \%$ \\
\hline 3 & $\begin{array}{l}\text { benzoic acid ( } 1.8 \text { equiv), DCC ( } 1.8 \text { equiv), DMAP } \\
\text { ( } 0.1 \text { equiv), } \mathrm{CH}_{2} \mathrm{Cl}_{2}, 20^{\circ} \mathrm{C}, 12 \mathrm{~h}\end{array}$ & 9 & $82 \%$ \\
\hline
\end{tabular}

astarting material 8 was recovered in ca. $80 \%$ yield.

was obtained in yields lower than $20 \%$, along with ca. $80 \%$ of recovered starting material 8 (Table 2, entry 2). Benzoate 9 was eventually obtained in high yields from benzoic acid using Steglich's esterification [61] (Table 2, entry 3).

With enal 9 in hands, selective hydrogenation of the C-C double bond had to be accomplished in the next step. Lipshutz' modification [62] of Stryker's reagent [63], which we had previously used successfully for the conjugate reduction of a related enoate [35], failed completely in this case and resulted only in the isolation of unreacted starting material. For these reasons we resumed to a hydrogenation catalyzed by $\mathrm{Pd} / \mathrm{C}$, in spite of the well-known capricious nature of these transformations [64]. 
With a commercial sample of Pd on charcoal (10 wt \%) a plethora of products was detected, four of which could be isolated and identified as the hydrogenated acetal 11, the methyl ether 13, and the two desilylated products 14 and 15 (Table 3, entry 1). Literature precedence exists for the $\mathrm{Pd} / \mathrm{C}$-induced dealkoxylation of acetals [65] and for desilylation reactions of silyl ethers [66]. With in situ generated $\mathrm{Pd} / \mathrm{C}$ (obtained from $\mathrm{Pd}(\mathrm{OAc})_{2}$ and charcoal according to Felpin's protocol) [67] an improved selectivity was observed as the cleavage of the silyl groups could be suppressed. However, reductive dealkoxylation of the acetal remained a problem and the combined yield of the desired products $\mathbf{1 1}$ and $\mathbf{1 2}$ was still unsatisfactory (Table 3, entry 2). This situation changed when we used $\mathrm{Pd}(\mathrm{OH})_{2}$ on charcoal $(10 \mathrm{wt} \%)$ as hydrogenation catalyst, which resulted in the exclusive formation of acetal $\mathbf{1 1}$ and aldehyde $\mathbf{1 2}$ in $83 \%$ combined yield (Table 3 , entry 3 ).

For the deprotection of $\mathbf{1 1}$ and $\mathbf{1 2}$ a desilylation initiated by TBAF, followed by acidic hydrolysis was investigated first. With isolated acetal 11, these conditions induced a scrambling of the benzoate and led to a mixture of the desired pyranose $\mathbf{1 6}$ and the furanose 17. Facile migration of carboxylates upon TBAF-mediated desilylation of a vicinal alcohol has previously been observed by us in a different context [68]. We assume that this process starts with a nucleophilic attack of the alkoxylate $\mathbf{1 8}$ at the ester carbon, giving a five membered intermediate $\mathbf{1 9}$ (Scheme 2).
The benzoate scrambling was completely suppressed by avoiding highly nucleophilic alkoxide intermediates, which was achieved with acidic deprotection conditions. Thus, treating the mixture of $\mathbf{1 1}$ and $\mathbf{1 2}$ with trifluoroacetic acid in dichloromethane at ambient temperature resulted in desilylation and acetal cleavage, giving 4-benzoyl protected L-amicetose $\mathbf{1 6}$ as an anomeric mixture in $65 \%$ yield (Scheme 3 ).

With a view towards L-cinerulose, formally the C4-oxidation product of L-amicetose, we started from cross metathesis product 8 which was first oxidized using Dess-Martin periodinane [69]. The $\alpha, \beta$-unsaturated $\gamma$-keto aldehyde 21 was obtained in a very high yield of $90 \%$, and subsequently subjected to hydrogenation conditions using a commercial sample of $\mathrm{Pd} / \mathrm{C}$ (10 wt \%, "batch 1"). We were pleased to find that the expected cinerulose derivative $\mathbf{2 2}$ could be isolated in analytically pure form in $85 \%$ yield (Scheme 4 ).

To our great dismay, we found that this result could not be reproduced with a different batch of commercial $\mathrm{Pd} / \mathrm{C}$ (10 wt \%, "batch 2"), purchased from the same supplier. As can be seen from Table 4 , entry 1 , the second batch of $\mathrm{Pd} / \mathrm{C}$ catalyzes under otherwise identical conditions a chemoselective acetalization of the aldehyde, leading to $\mathbf{2 3}$ which was isolated in $52 \%$ yield. A similar result was obtained with $\mathrm{Pd}(\mathrm{OH})_{2} / \mathrm{C}$ (Table 4, entry 2). In situ formed Pd on charcoal [67], prepared from $0.5 \mathrm{~mol} \%$ of $\mathrm{Pd}(\mathrm{OAc})_{2}$ as a precursor, gave an insepa-

Table 3: Hydrogenation of benzoyl protected enal 9.

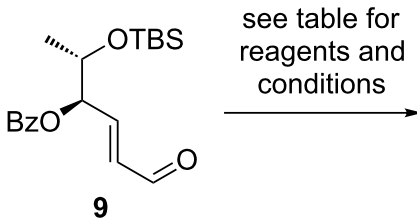

9

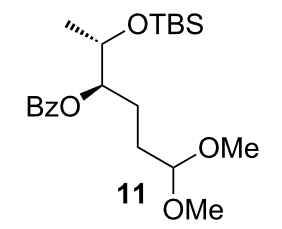<smiles>CC(=O)OC(C)C(CCC=O)O[SbH3]</smiles>

12

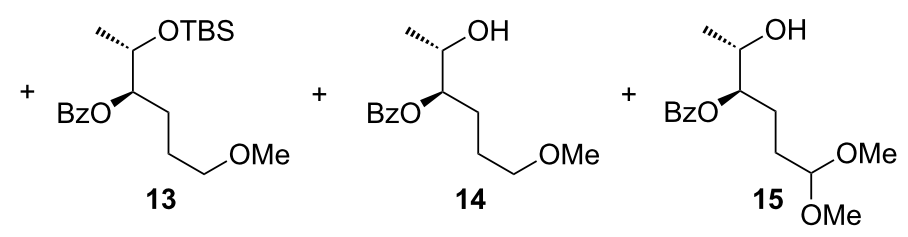

\begin{tabular}{|c|c|c|c|c|c|c|}
\hline entry & reagents and conditions & 11 & 12 & 13 & 14 & 15 \\
\hline 1 & $\mathrm{Pd} / \mathrm{C}(10 \mathrm{wt} \% ; 1.6 \mathrm{~mol} \%), \mathrm{H}_{2}(1 \mathrm{bar})$, methanol, $20{ }^{\circ} \mathrm{C}, 12 \mathrm{~h}$ & $31 \%$ & - & $16 \%$ & $16 \%$ & $8 \%$ \\
\hline 2 & $\begin{array}{l}\mathrm{Pd}(\mathrm{OAc})_{2}(1 \mathrm{~mol} \%) \text {, activated charcoal }(9 \mathrm{~mol} \%), \mathrm{H}_{2}(1 \mathrm{bar}) \text {, } \\
\text { methanol, } 20^{\circ} \mathrm{C}, 12 \mathrm{~h}\end{array}$ & $28 \%$ & $9 \%$ & trace & - & - \\
\hline $3^{a}$ & $\mathrm{Pd}(\mathrm{OH})_{2} / \mathrm{C}(10$ wt $\% ; 1.2 \mathrm{~mol} \%), \mathrm{H}_{2}(1 \mathrm{bar})$, methanol, $20{ }^{\circ} \mathrm{C}, 12 \mathrm{~h}$ & $51 \%$ & $32 \%$ & - & - & - \\
\hline
\end{tabular}

aproducts 11 and 12 were obtained as an inseparable mixture, yields are estimated from ${ }^{1} \mathrm{H}$ NMR spectrum. 


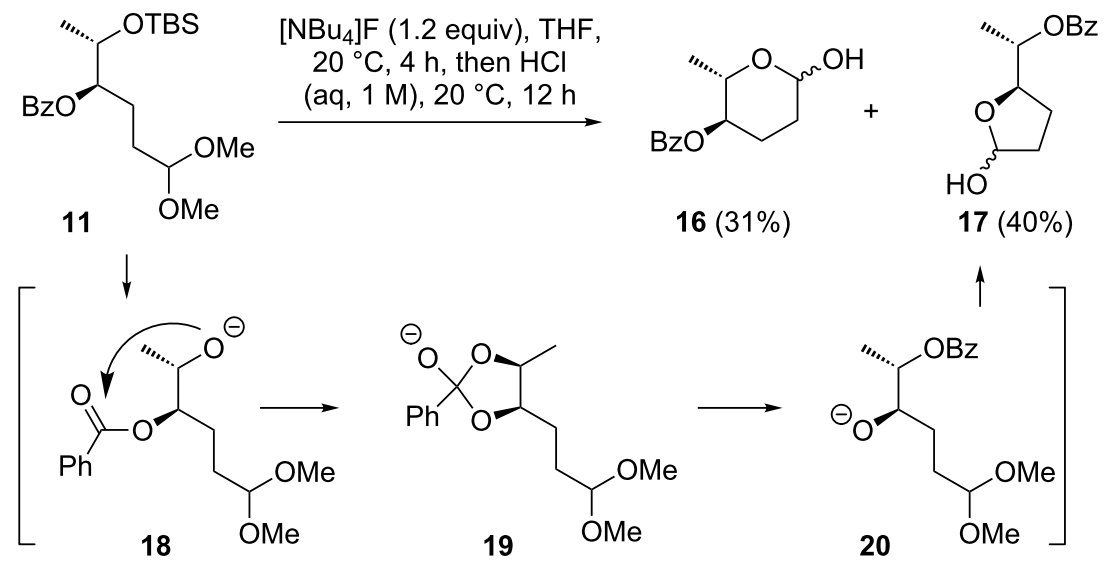

Scheme 2: Two step desilylation-acetal hydrolysis.<smiles>[C+]OC(CCC(OC)OC)C(C)O[Na]</smiles>

11<smiles></smiles>

12
$\mathrm{CH}_{2} \mathrm{Cl}_{2} / \mathrm{CF}_{3} \mathrm{CO}_{2} \mathrm{H}$

(4:1); $20^{\circ} \mathrm{C} ; 20 \mathrm{~h}$<smiles>C[C@H]1O[C@H](O)CC[C@@H]1OC(=O)OCc1ccccc1</smiles>

$16(65 \%)$

Scheme 3: Deprotection of 11 and 12 to L-amicetose derivative 16.

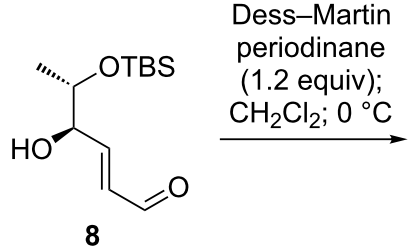

8<smiles>C[C@@H](O[Sb])C(=O)/C=C/C=O</smiles>

$21(90 \%)$

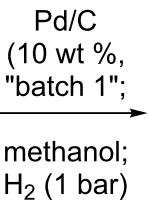<smiles>C[C@@H](CCC=O)O[C@H](C)C(=O)CCC=O</smiles>

$22(85 \%)$

Scheme 4: Synthesis of a cinerulose-TBS ether 22.

Table 4: Chemoselective acetalization of oxidation product 21<smiles>C[C@@H](O[Sb])C(=O)/C=C/C=O</smiles>

21<smiles>COC(C=CC(=O)C(C)OC)OC</smiles>

23

\begin{tabular}{|c|c|c|}
\hline entry & reagents and conditions & yield of 23 \\
\hline 1 & $\mathrm{Pd} / \mathrm{C}$ ("batch 2", 10 wt \%; $2.2 \mathrm{~mol} \%), \mathrm{H}_{2}$ (1 bar), methanol, $20^{\circ} \mathrm{C}, 12 \mathrm{~h}$ & $52 \%$ \\
\hline 2 & $\mathrm{Pd}(\mathrm{OH})_{2} / \mathrm{C}(10 \mathrm{wt} \% ; 1,7 \mathrm{~mol} \%), \mathrm{H}_{2}(1 \mathrm{bar})$, methanol, $20{ }^{\circ} \mathrm{C}, 12 \mathrm{~h}$ & $43 \%$ \\
\hline 3 & $\mathrm{Pd}(\mathrm{OAc})_{2}(0.5 \mathrm{~mol} \%)$, activated charcoal $(9 \mathrm{~mol} \%), \mathrm{H}_{2}(1 \mathrm{bar})$, methanol, $20^{\circ} \mathrm{C}, 12 \mathrm{~h}$ & $34 \% \mathrm{a}$ \\
\hline 4 & $\mathrm{Pd}(\mathrm{OAc})_{2}(1.0 \mathrm{~mol} \%)$, activated charcoal $(9 \mathrm{~mol} \%), \mathrm{H}_{2}(1 \mathrm{bar})$, methanol, $20{ }^{\circ} \mathrm{C}, 12 \mathrm{~h}$ & $82 \%$ \\
\hline
\end{tabular}

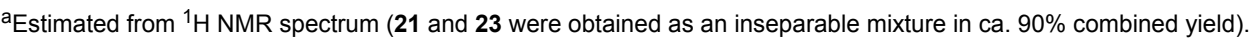


rable mixture of starting material 21 and acetal 23 in a 1.7:1 ratio (Table 4, entry 3 ). By increasing the amount of catalyst precursor to $1 \mathrm{~mol} \%$, conversion to acetal 23 was complete, and this product could be isolated in $82 \%$ yield (Table 4 , entry 4).

Although the Pd(II)-catalyzed acetalization of aldehydes, including enals, is known [70], we are not aware of examples where Pd-catalysts immobilized on charcoal have been used for this transformation. Most likely the acetalization is catalyzed by residual $\mathrm{Pd}^{2+}$ via Lewis-acidic carbonyl activation. It is known that the reduction to $\operatorname{Pd}(0)$ is almost never complete, even if hydrogen is present $[71,72]$.

At this stage we decided to reinvestigate the hydrogenation step, starting from acetal $\mathbf{2 3}$, using fresh samples of catalyst which have not been used previously for the acetalization (Table 5). With in situ prepared $\mathrm{Pd} / \mathrm{C}$ (Table 5, entry 1) a major amount of starting material 23 was recovered and minor quantities of hydrogenated products $\mathbf{2 4}$ and $\mathbf{2 6}$, as well as desilylated starting material 25 were detected. With commercial Pd/C (10 wt \%, "batch 2") (Table 5, entry 2) the starting material was fully consumed and only hydrogenated products $\mathbf{2 4}$ and $\mathbf{2 6}$ could be detected in a 1:2 ratio, but unfortunately the isolated yields were only mediocre. As for the hydrogenation of benzoate 9 (Table 3), best results were reproducibly obtained with $\mathrm{Pd}(\mathrm{OH})_{2}$ on charcoal (Table 5, entry 3), leading to an isolated yield of $84 \%$ of a double protected cinerulose derivative $\mathbf{2 4}$.

All attempts to isolate cinerulose were hampered by the high volatility of the product. To accomplish complete deprotection of the precursor, compound $\mathbf{2 4}$ was first treated with TBAF trihydrate in THF, followed by treatment with diluted aqueous $\mathrm{HCl}$. Although only small amounts of material were obtained via this procedure, ${ }^{1} \mathrm{H}$ NMR spectroscopical analysis was possible. The data suggest that cinerulose exists in $\mathrm{CDCl}_{3}$ as a 2:1 mixture of acyclic aldose $\mathbf{2 7}$ and lactol $\mathbf{2 8}$ (Scheme 5).

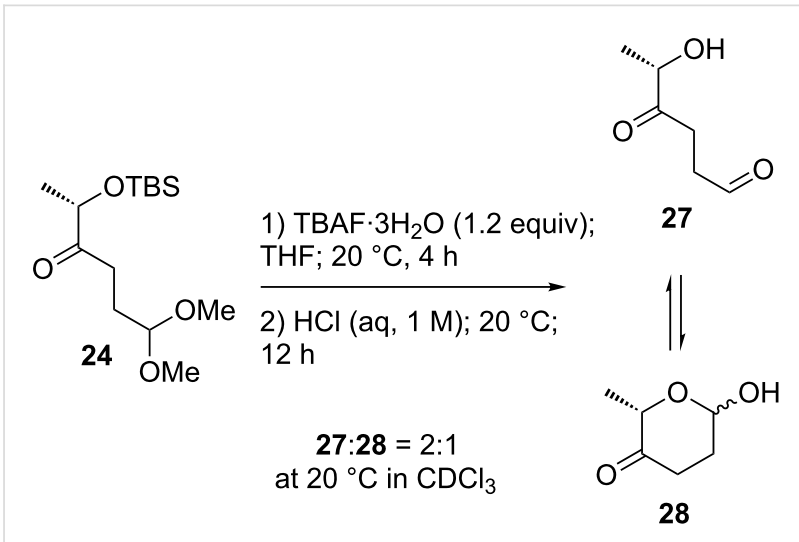

Scheme 5: Deprotection of 24.

\section{Conclusion}

In summary, we showed that an allylic alcohol, available diastereoselectively from enantiomerically pure L-lactate in few steps, is a useful starting material for a metathesis based synthesis of protected L-amicetose and L-cinerulose. It undergoes a clean and high yielding cross metathesis reaction with acrolein, however, the most commonly used second generation Grubbs' catalyst is not the ideal initiator for this particular transformation. Significantly better results were obtained with two different phosphine free catalysts comprising a hemilabile alkoxy substituted benzylidene ligand, even at only moderately elevated temperatures. The acrolein cross metathesis product can be converted into the 4-benzoate of L-amicetose via benzoylation, Pd-catalyzed hydrogenation and global deprotection, whereas a cinerulose derivative protected at $\mathrm{C} 1$ as a

Table 5: Hydrogenation of acetal 23
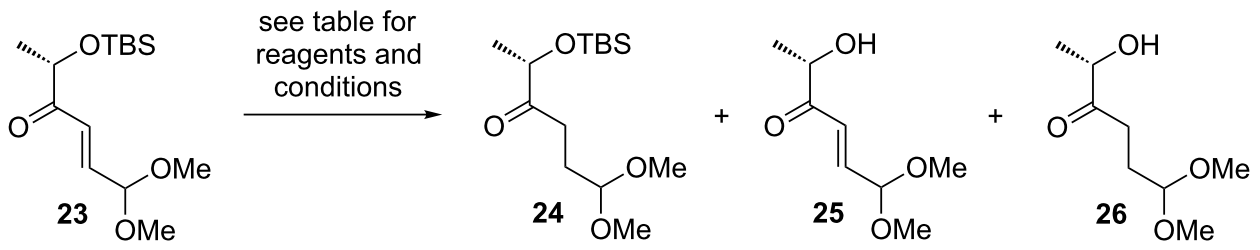

\begin{tabular}{|c|c|c|c|c|}
\hline entry & reagents and conditions & 24 & 25 & 26 \\
\hline $1^{a}$ & $\mathrm{Pd}(\mathrm{OAc})_{2}(1.0 \mathrm{~mol} \%)$, activated charcoal $(9 \mathrm{~mol} \%), \mathrm{H}_{2}(1 \mathrm{bar})$, methanol, $20^{\circ} \mathrm{C}, 12 \mathrm{~h}$ & $7 \%$ & $16 \%$ & $7 \%$ \\
\hline 2 & $\mathrm{Pd} / \mathrm{C}(10 \mathrm{wt} \% ; 2.2 \mathrm{~mol} \%), \mathrm{H}_{2}$ (1 bar), methanol, $20^{\circ} \mathrm{C}, 12 \mathrm{~h}$ & $19 \%$ & n.d. & $38 \%$ \\
\hline 3 & $\mathrm{Pd}(\mathrm{OH})_{2} / \mathrm{C}(10$ wt $\% ; 1.0 \mathrm{~mol} \%), \mathrm{H}_{2}(1 \mathrm{bar})$, methanol, $20^{\circ} \mathrm{C}, 12 \mathrm{~h}$ & $84 \%$ & n.d. & n.d. \\
\hline
\end{tabular}

astarting material 23 (49\%) was recovered. 
dimethyl acetal and at $\mathrm{C} 5-\mathrm{OH}$ as a TBS ether becomes available via Dess-Martin oxidation, Pd-catalyzed acetalization and Pd-catalyzed hydrogenation. Notably, our results underline once again that apparently trivial olefin hydrogenation reactions catalyzed by commercial " $\mathrm{Pd} / \mathrm{C}$ " can be capricious and very difficult to reproduce, unless the specific properties of the catalyst used and the conditions for its preparation are documented by the supplier. Unfortunately, this is very often not the case and the catalytic activities of apparently identical catalysts which are often designated just as " $10 \mathrm{wt} \% \mathrm{Pd}$ on carbon" may vary dramatically.

\section{Supporting Information}

\section{Supporting Information File 1}

Experimental procedures and analytical data. [http://www.beilstein-journals.org/bjoc/content/ supplementary/1860-5397-10-102-S1.pdf]

\section{Supporting Information File 2}

Copies of ${ }^{1} \mathrm{H}$ and ${ }^{13} \mathrm{C}$ NMR spectra.

[http://www.beilstein-journals.org/bjoc/content/

supplementary/1860-5397-10-102-S2.pdf]

\section{Acknowledgements}

Generous financial support by the Deutsche Forschungsgemeinschaft (DFG grant Schm 1095/6-2) is gratefully acknowledged. We thank Evonik Oxeno for generous donations of solvents, and Umicore for generous donations of metathesis catalysts.

\section{References}

1. La Ferla, B.; Airoldi, C.; Zona, C.; Orsato, A.; Cardona, F.; Merlo, S.; Sironi, E.; D'Orazio, G.; Nicotra, F. Nat. Prod. Rep. 2011, 28, 630-648. doi:10.1039/c0np00055h

2. Gräfe, U. Biochemie der Antibiotika; Spektrum Verlag: Heidelberg, Germany, 1992.

3. Hoffmeister, D.; Dräger, G.; Ichinose, K.; Rohr, J.; Bechthold, A. J. Am. Chem. Soc. 2003, 125, 4678-4679. doi:10.1021/ja029645k

4. Hoffmeister, D.; Weber, M.; Dräger, G.; Ichinose, K.; Dürr, C.; Bechthold, A. ChemBioChem 2004, 5, 369-371. doi:10.1002/cbic.200300793

5. Pérez, M.; Lombó, F.; Zhu, L.; Gibson, M.; Braña, A. F.; Rohr, J.; Salas, J. A.; Méndez, C. Chem. Commun. 2005, 1604-1606. doi:10.1039/b417815g

6. Kirschning, A.; Bechthold, A. F.-W.; Rohr, J. Top. Curr. Chem. 1997, 188, 1-84. doi:10.1007/BFb0119234

7. Kunimoto, S.; Someno, T.; Yamazaki, Y.; Lu, J.; Esumi, H.; Naganawa, H. J. Antibiot. 2003, 56, 1012-1017. doi:10.7164/antibiotics.56.1012

8. Someno, T.; Kunimoto, S.; Nakamura, H.; Naganawa, H.; Ikeda, D. J. Antibiot. 2005, 58, 56-60. doi:10.1038/ja.2005.6
9. Lu, J.; Kunimoto, S.; Yamazaki, Y.; Kaminishi, M.; Esumi, H. Cancer Sci. 2004, 95, 547-552. doi:10.1111/j.1349-7006.2004.tb03247.x

10. Arcamone, F.; Cassinelli, G. Curr. Med. Chem. 1998, 5, 391-419.

11. Oki, T.; Matsuzawa, Y.; Yoshimoto, A.; Numata, K.; Kitamura, I.; Hori, S.; Takamatsu, A.; Umezawa, H.; Ishizuka, M.; Naganawa, H.; Suda, H.; Hamada, M.; Takeuchi, T. J. Antibiot. 1975, 28, 830-834. doi:10.7164/antibiotics.28.830

12. Komiyama, T.; Oki, T.; Inui, T.; Takeuchi, T.; Umezawa, H. Gann 1979, 70, 395-401.

13. Lee, Y.-L.; Chen, C.-W.; Liu, F.-H.; Huang, Y.-W.; Huang, H.-M. PLoS One 2013, 8, e61939. doi:10.1371/journal.pone.0061939

14. Kirschning, A.; Jesberger, M.; Schöning, K.-U. Synthesis 2001, 507-540. doi:10.1055/s-2001-12342

15. Thiem, J.; Klaffke, W. Top. Curr. Chem. 1990, 154, 285-332. doi:10.1007/BFb0111564

16. Seeberger, P. H.; Danishefsky, S. J. Acc. Chem. Res. 1998, 31 , 685-695. doi:10.1021/ar9600648

17. Seeberger, P. H.; Haase, W.-C. Chem. Rev. 2000, 100, 4349-4394. doi:10.1021/cr9903104

18. Lajšić, S.; Miljković, D.; Ćetković, G. Carbohydr. Res. 1992, 233, 261-264. doi:10.1016/S0008-6215(00)90940-6

19. Bethell, G. S.; Ferrier, R. J. J. Chem. Soc., Perkin Trans. 1 1973, 1400-1405. doi:10.1039/p19730001400

20. Pedersen, C.; Jensen, H. S. Acta Chem. Scand. 1994, 48, 222-227. doi:10.3891/acta.chem.scand.48-0222

21. Spohr, U.; Paszkiewicz-Hnatiw, E.; Morishima, N.; Lemieux, R. U. Can. J. Chem. 1992, 70, 254-271. doi:10.1139/v92-036

22. Kjølberg, O.; Neumann, K. Acta Chem. Scand. 1992, 46, 877-882. doi:10.3891/acta.chem.scand.46-0877

23. Wang, H.-Y. L.; Wu, B.; Zhang, Q.; Kang, S.-W.; Rojanasakul, Y.; O'Doherty, G. A. ACS Med. Chem. Lett. 2011, 2, 259-263. doi:10.1021/ml100291n

24. Wang, H.-Y. L.; Xin, W.; Zhou, M.; Stueckle, T. A.; Rojanasakul, Y.; O'Doherty, G. A. ACS Med. Chem. Lett. 2011, 2, 73-78. doi:10.1021/ml100219d

25. Zhu, L.; Talukdar, A.; Zhang, G.; Kedenburg, J. P.; Wang, P. G. Synlett 2005, 1547-1550. doi:10.1055/s-2005-869846

26. Kirschning, A.; Hary, U.; Ries, M. Tetrahedron 1995, 51, 2297-2304. doi:10.1016/0040-4020(94)01081-A

27. Noecker, L. A.; Martino, J. A.; Foley, P. J.; Rush, D. M.; Giuliano, R. M.; Villani, F. J., Jr. Tetrahedron: Asymmetry 1998, 9, 203-212. doi:10.1016/S0957-4166(97)00631-9

28. Berti, G.; Caroti, P.; Catelani, G.; Monti, L. Carbohydr. Res. 1983, 124, 35-42. doi:10.1016/0008-6215(83)88353-0

29. Marco, J. L. Synth. Commun. 1989, 19, 485-490. doi:10.1080/00397918908050690

30. Itoh, T.; Yoshinaka, A.; Sato, T.; Fujisawa, T. Chem. Lett. 1985, 14, 1679-1680. doi:10.1246/cl.1985.1679

31. Fuganti, C.; Grasselli, P. J. Chem. Soc., Chem. Commun. 1978, 299-300. doi:10.1039/c39780000299

32. Aidhen, I. S.; Satyamurthi, N. Indian J. Chem., Sect. B: Org. Chem. Incl. Med. Chem. 2008, 47, 1851-1857.

33. McDonald, F. E.; Zhu, H. Y. H. J. Am. Chem. Soc. 1998, 120, 4246-4247. doi:10.1021/ja980196r

34. Zhu, L.; Kedenburg, J. P.; Xian, M.; Wang, P. G. Tetrahedron Lett. 2005, 46, 811-813. doi:10.1016/j.tetlet.2004.12.014

35. Schmidt, B.; Hauke, S. Org. Biomol. Chem. 2013, 11, 4194-4206. doi:10.1039/c3ob40167g 
36. Schmidt, B.; Biernat, A. Chem.-Eur. J. 2008, 14, 6135-6141. doi:10.1002/chem.200800567

37. Ley, S. V.; Armstrong, A.; Díez-Martín, D.; Ford, M. J.; Grice, P.; Knight, J. G.; Kolb, H. C.; Madin, A.; Marby, C. A.; Mukherjee, S.; Shaw, A. N.; Slawin, A. M. Z.; Vile, S.; White, A. D.; Williams, D. J.; Woods, M. J. Chem. Soc., Perkin Trans. 1 1991, 667-692. doi:10.1039/p19910000667

38. Chatterjee, A. K.; Morgan, J. P.; Scholl, M.; Grubbs, R. H. J. Am. Chem. Soc. 2000, 122, 3783-3784. doi:10.1021/ja9939744

39. Cossy, J.; BouzBouz, S.; Hoveyda, A. H. J. Organomet. Chem. 2001, 624, 327-332. doi:10.1016/S0022-328X(00)00932-3

40. Dinh, M.-T.; BouzBouz, S.; Peglion, J.-L.; Cossy, J. Synlett 2005, 2851-2853. doi:10.1055/s-2005-918943

41. Chandra Rao, D.; Kumar Reddy, D.; Shekhar, V.; Venkateswarlu, Y. Tetrahedron Lett. 2013, 54, 828-829. doi:10.1016/j.tetlet.2012.11.061

42. Miao, X.; Fischmeister, C.; Bruneau, C.; Dixneuf, P. H. ChemSusChem 2009, 2, 542-545. doi:10.1002/cssc.200900028

43. Mohapatra, D. K.; Maity, S.; Rao, T. S.; Yadav, J. S.; Sridhar, B. Eur. J. Org. Chem. 2013, 2859-2863. doi:10.1002/ejoc.201300053

44. Paul, T.; Andrade, R. B. Tetrahedron Lett. 2007, 48, 5367-5370. doi:10.1016/j.tetlet.2007.06.031

45. Achmatowicz, O.; Szechner, B. B. Bull. Acad. Pol. Sci., Ser. Sci. Chim. 1971, 19, 309-311.

46. Scholl, M.; Ding, S.; Lee, C. W.; Grubbs, R. H. Org. Lett. 1999, 1, 953-956. doi:10.1021/ol990909q

47. Garber, S. B.; Kingsbury, J. S.; Gray, B. L.; Hoveyda, A. H. J. Am. Chem. Soc. 2000, 122, 8168-8179. doi:10.1021/ja001179g

48. Gessler, S.; Randl, S.; Blechert, S. Tetrahedron Lett. 2000, 41, 9973-9976. doi:10.1016/S0040-4039(00)01808-6

49. Arlt, D.; Bieniek, M.; Karch, R. Novel Metathesis Catalysts. WO Pantent Applcation WO2008/034552 A1, March 27, 2008.

50. Mutlu, H.; Montero de Espinosa, L.; Türünç, O.; Meier, M. A. R. Beilstein J. Org. Chem. 2010, 6, 1149-1158. doi:10.3762/bjoc.6.131

51. Schmidt, B. Eur. J. Org. Chem. 2004, 1865-1880. doi:10.1002/ejoc.200300714

52. Schmidt, B. J. Mol. Catal. A 2006, 254, 53-57. doi:10.1016/j.molcata.2006.03.026

53. Higman, C. S.; Plais, L.; Fogg, D. E. ChemCatChem 2013, 5 , 3548-3551. doi:10.1002/cctc.201300886

54. Forman, G. S.; McConnell, A. E.; Tooze, R. P.; van Rensburg, W. J.; Meyer, W. H.; Kirk, M. M.; Dwyer, C. L.; Serfontein, D. W. Organometallics 2005, 24, 4528-4542. doi:10.1021/om0503848

55. Forman, G. S.; Tooze, R. P. J. Organomet. Chem. 2005, 690, 5863-5866. doi:10.1016/j.jorganchem.2005.07.107

56. Samojłowicz, C.; Bieniek, M.; Grela, K. Chem. Rev. 2009, 109, 3708-3742. doi:10.1021/cr800524f

57. Connon, S. J.; Blechert, S. Angew. Chem., Int. Ed. 2003, 42, 1900-1923. doi:10.1002/anie.200200556

58. Connon, S. J.; Blechert, S. Top. Organomet. Chem. 2004, 11, 93-124.

59. Schmidt, B.; Kunz, O.; Petersen, M. H. J. Org. Chem. 2012, 77, 10897-10906. doi:10.1021/jo302359h

60. Schmidt, B.; Kunz, O. Beilstein J. Org. Chem. 2013, 9, 2544-2555. doi:10.3762/bjoc.9.289

61. Neises, B.; Steglich, W. Angew. Chem., Int. Ed. Engl. 1978, 17, 522-524. doi:10.1002/anie.197805221

62. Baker, B. A.; Bošković, Z. V.; Lipshutz, B. H. Org. Lett. 2008, 10, 289-292. doi:10.1021/ol702689v

63. Mahoney, W. S.; Brestensky, D. M.; Stryker, J. M. J. Am. Chem. Soc. 1988, 110, 291-293. doi:10.1021/ja00209a048
64. Young, J. G.; Hartung, W. H.; Daniels, H. H. J. Org. Chem. 1953, 18 229-234. doi:10.1021/jo01130a015

65. Haukaas, M. H.; O'Doherty, G. A. Org. Lett. 2002, 4, 1771-1774. doi:10.1021/ol025844x

66. Kim, S.; Jacobo, S. M.; Chang, C.-T.; Bellone, S.; Powell, W. S.; Rokach, J. Tetrahedron Lett. 2004, 45, 1973-1976. doi:10.1016/j.tetlet.2003.12.145

67. Felpin, F.-X.; Fouquet, E. Chem.-Eur. J. 2010, 16, 12440-12445. doi:10.1002/chem.201001377

68. Schmidt, B.; Kunz, O.; Biernat, A. J. Org. Chem. 2010, 75, 2389-2394. doi:10.1021/jo1002642

69. Zhdankin, V. V.; Stang, P. J. Chem. Rev. 2008, 108, 5299-5358. doi:10.1021/cr800332c

70. Gorla, F.; Venanzi, L. M. Helv. Chim. Acta 1990, 73, 690-697. doi:10.1002/hlca.19900730317

71. Seki, M. Synthesis 2006, 2975-2992. doi:10.1055/s-2006-950197

72. Felpin, F.-X.; Ayad, T.; Mitra, S. Eur. J. Org. Chem. 2006, 2679-2690. doi:10.1002/ejoc.200501004

\section{License and Terms}

This is an Open Access article under the terms of the Creative Commons Attribution License (http://creativecommons.org/licenses/by/2.0), which permits unrestricted use, distribution, and reproduction in any medium, provided the original work is properly cited.

The license is subject to the Beilstein Journal of Organic Chemistry terms and conditions:

(http://www.beilstein-journals.org/bjoc)

The definitive version of this article is the electronic one which can be found at: doi:10.3762/bjoc. 10.102 